\title{
Virulence Structure of the Eastern U.S. Wheat Powdery Mildew Population
}

\author{
Ryan Parks, United States Department of Agriculture-Agricultural Research Service (USDA-ARS), Department of \\ Plant Pathology, North Carolina State University, Raleigh 27695; Ignazio Carbone, Department of Plant Pathology, \\ and J. Paul Murphy, Department of Crop Science, North Carolina State University, Raleigh 27695; and David \\ Marshall and Christina Cowger, USDA-ARS, Department of Plant Pathology, North Carolina State University, \\ Raleigh 27695
}

\begin{abstract}
Parks, R., Carbone, I., Murphy, J. P., Marshall, D., and Cowger, C. 2008. Virulence structure of the eastern U.S. wheat powdery mildew population. Plant Dis. 92:1074-1082.

Little is known about the population structure of wheat powdery mildew in the eastern United States, and the most recent report on virulence in this population involved isolates collected in 1993-94. In the present study, wheat leaves naturally infected with powdery mildew were collected from 10 locations in the southeastern United States in 2003 and 2005 and a collection of 207 isolates was derived from single ascospores. Frequencies of virulence to 16 mildew resistance $(P m)$ genes were determined by inoculating the isolates individually on replicated plates of detached leaves of differential wheat lines. These virulence frequencies were used to infer local effectiveness of $\mathrm{Pm}$ genes, estimate virulence complexity, detect significant associations between pairs of pathogen avirulence loci, and assess whether phenotypic differences between pathogen subpopulations increased with geographic distance. In both years, virulence to $P m 3 a$, $P m 3 c, P m 5 a$, and $P m 7$ was present in more than $90 \%$ of sampled isolates and virulence to Pmla, Pm16, Pm17, and Pm25 was present in fewer than 10\% of isolates. In each year, 71 to $88 \%$ of all sampled isolates possessed one of a few multilocus virulence phenotypes, although there were significant differences among locations in frequencies of virulence to individual $\mathrm{Pm}$ genes. Several significant associations were detected between alleles for avirulence to pairs of $P m$ genes. Genetic (phenotypic) distance between isolate subpopulations increased significantly $\left(R^{2}=0.40, P<0.001\right)$ with increasing geographic separation; possible explanations include different commercial deployment of $P m$ genes and restricted gene flow in the pathogen population.
\end{abstract}

Additional keywords: Blumeria graminis f. sp. tritici, Triticum aestivum

Blumeria graminis (DC.) Speer f. sp. tritici (Em. Marchal) causes powdery mildew of wheat (Triticum aestivum), a disease that may cause significant damage in many wheat-growing areas of the world, with yield losses up to $34 \%$ on susceptible cultivars (34). In fall-sown cereals, primary $B$. graminis inoculum is thought to originate mainly from cleistothecia (chasmothecia, or sexual fruiting bodies) produced at the end of the previous growing season by compatible mating types $(11,23)$. The main period of ascospore release is thought to be autumn $(39,42)$ but this may be environmentally dependent. Prior to leaf senescence and cleistothecial production in early summer, the pathogen undergoes multiple cycles of asexual reproduction (via conidia; 43). With annual

Corresponding author: R. Parks

E-mail: wrparks@ncsu.edu

Accepted for publication 4 March 2008.

doi:10.1094/PDIS-92-7-1074

This article is in the public domain and not copyrightable. It may be freely reprinted with customary crediting of the source. The American Phytopathological Society, 2008. sexual reproduction, virulence gene combinations may be shuffled frequently (45), allowing for selection of effective virulence combinations in fit backgrounds. Thus, virulence phenotypes are a more suitable method of characterizing individuals than "races," because each specific virulence phenotype may be ephemeral and there may not be a direct line of descent between individuals possessing the same virulence phenotype.

Current methods of wheat powdery mildew control are fungicides and resistant cultivars, with the majority of resistance being conferred by major resistance genes, known as $P m$ genes $(25,26,34)$. There are currently 53 identified alleles at 34 loci conferring resistance to wheat powdery mildew (19). Unfortunately, knowledge of which $P m$ genes are present in commonly grown wheat cultivars is scattered and incomplete. Extensive production of wheat cultivars with one or a few $\mathrm{Pm}$ genes places strong selective pressure on the pathogen population, and copious spore production provides ample potential for mutations to virulence, resulting in rapid appearance and increase of adapted isolates (45). Wind-aided conidial dispersal quickly spreads virulent individuals (41), leading to low durability of resistance and long-distance spread of new virulences $(2,15)$.

Numerous surveys of the $B$. graminis $\mathrm{f}$. sp. tritici population virulence have been performed in Europe $(7,16,28,38,45)$ and several regional surveys have been done in the United States $(21,27,32,34,35)$. However, the most recent U.S. survey was conducted on isolates collected in 1993 and 1994 (34). Cultivars used by growers have changed since 1994. For instance, cultivars with Pm17 (12,13) were released in 2002 and were widely planted in the eastern United States starting in 2003. Changing selective pressures caused by widespread use of new resistance genes can rapidly alter population virulence frequencies (41), potentially leading to a breakdown of mildew resistance such as that observed in cv. Roane in the eastern United States in the late 1990s (J. P. Murphy, personal observation).

Wheat breeders use virulence data determined from mildew population surveys to prioritize $\mathrm{Pm}$ genes for incorporation into breeding materials (16). Breeders rely on observations of field nurseries to determine the effectiveness of $P m$ genes, but epidemics may not occur with adequate frequency or intensity for germplasm evaluation. An up-to-date survey of eastern U.S. wheat powdery mildew virulence can assist resistance breeding by providing information for evaluation of breeding lines and can facilitate cultivar selection by growers.

Gene pyramiding is considered an important strategy in breeding for resistance to wheat powdery mildew (18). Such pyramids are likely to be less durable, however, if virulence to the individual $\mathrm{Pm}$ genes has already become common, because the resistance pyramid would then rapidly select for "virulence pyramids" in the pathogen population (4). Having up-todate virulence frequency data facilitates pyramiding of $\mathrm{Pm}$ genes to which virulence in the population remains rare.

Past virulence studies have indicated that the eastern U.S. mildew population is subdivided between the northeastern and southeastern states, such that virulence to individual $\mathrm{Pm}$ genes may differ in the two regions (24). It is unknown whether such differences result mainly from recent appearance of resistance-breaking isolates, 
restricted gene flow between localities, or disparities in use of $\mathrm{Pm}$ genes among wheat-growing regions.

Our objectives were to (i) determine powdery mildew virulence frequencies in locations representative of eastern U.S. wheat production and compare them with frequencies reported a decade ago (34), (ii) analyze virulence differences among geographic locations, and (iii) investigate possible associations among alleles at pathogen avirulence loci. In order to make these assessments, a collection of B. graminis $\mathrm{f}$. sp. tritici isolates was randomly derived from single ascospores released from fieldsampled cleistothecia, and the isolates were tested on a set of $P m$ differential wheat lines in the laboratory.

\section{MATERIALS AND METHODS}

Sample collection and isolation preparation. Samples of cleistothecia on senescent wheat leaves from the eastern United States (Fig. 1) were collected by collaborators in 2003 and 2005 (Table 1). The locations were those in which conditions were conducive to wheat mildew epidemics in those years, and the crops sampled were research plots. Cleistothecia from highly susceptible cultivars were sampled because it was assumed that those cultivars possessed either no $\mathrm{Pm}$ genes or only defeated $P m$ genes and, thus, the mildew samples would not be biased by selection for virulence. Multiple leaves were sampled from each plot and several plots were sampled in each field when possible (Table 1). Each leaf bore numerous cleistothecia. Little is known about the spatial structuring of $B$. graminis populations; however, because primary inoculum is thought to consist of airborne ascospores, this sampling protocol was taken as representative of the diversity present at the sampling locations.

The method of Niewoehner and Leath (34) was modified as follows to more rapidly obtain isolates derived from single ascospores. Ascospore release was induced by placing leaves bearing cleistothecia on moist filter paper in the lid of a petri plate, and placing the plate in a growth chamber at $17^{\circ} \mathrm{C}$ with $12 \mathrm{~h}$ of light. After 4 days, detached leaves of the susceptible cvs. Jagalene (PVP 200200160) or Chancellor (CI 12333) were placed on benzimidazoleamended $0.5 \%$ water agar at $50 \mathrm{mg} / \mathrm{liter}$ under the maturing cleistothecia. After 24 $\mathrm{h}$, the detached leaves were removed from beneath the cleistothecia and placed in a $17^{\circ} \mathrm{C}$ growth chamber with $12 \mathrm{~h}$ of light, and fresh detached leaves were placed under the maturing ascospores for $24 \mathrm{~h}$. This process was repeated for at least 7 days to ensure that an adequate number of ascospores were allowed to germinate on susceptible tissue.

Seven days after removal from beneath the maturing cleistothecia, detached leaves were examined for mildew colonies. Under a dissecting microscope, individual colonies were subcultured using a dissecting needle to transfer conidia to fresh leaf tissue. When possible, two or three isolates were recovered from each cleistothecia-bearing leaf. Subcultured single- ascospore isolates were placed in a $17^{\circ} \mathrm{C}$ growth chamber with $12 \mathrm{~h}$ of light. After 8 days, each isolate was increased on six detached-leaf petri plates. If enough conidia were not available to inoculate at least six petri plates, two or three plates

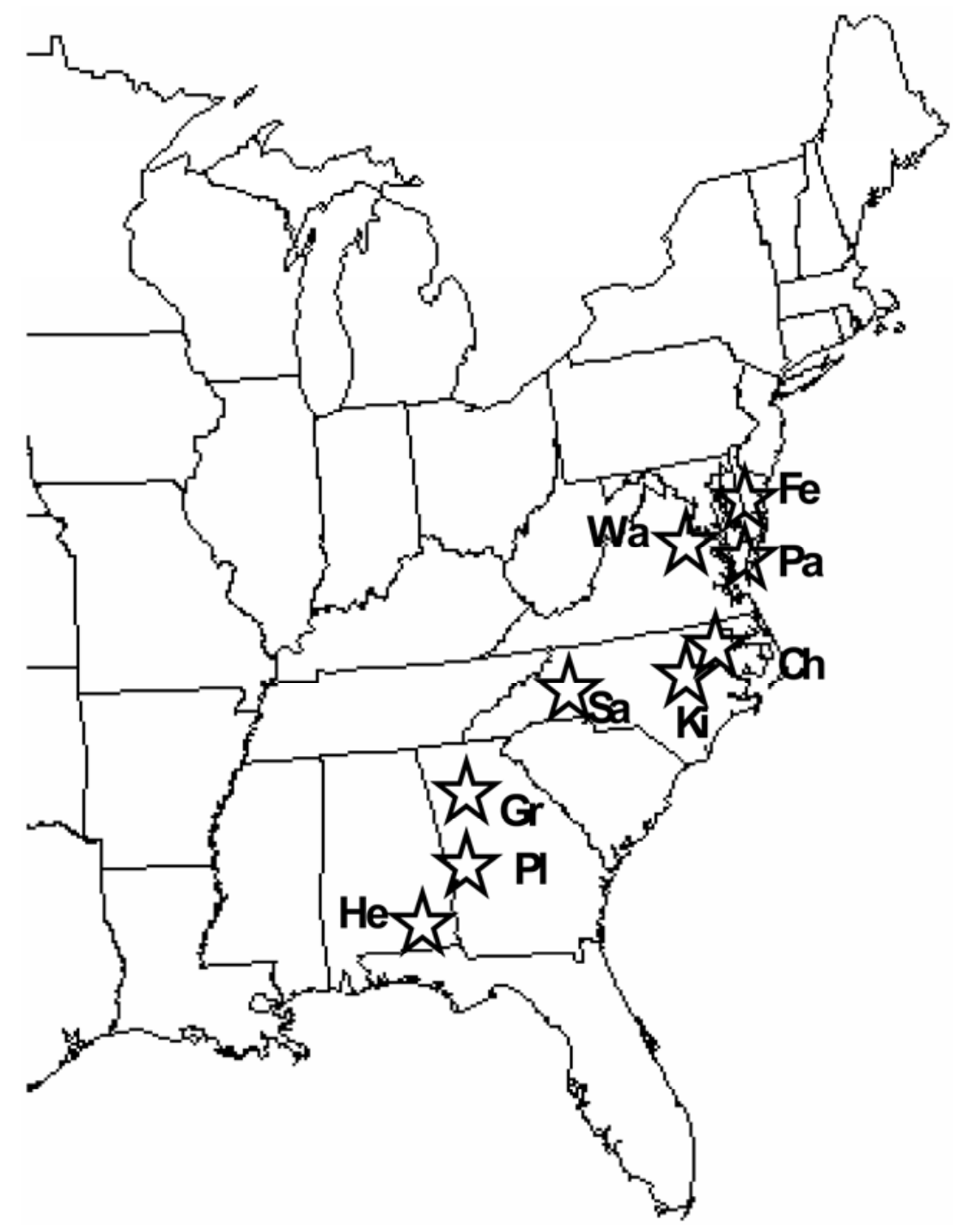

Fig. 1. Locations where wheat leaves infected with powdery mildew were collected in $2003(\mathrm{Gr}=$ Griffin, GA; Ki = Kinston, NC; Sa $=$ Salisbury, NC; and Wa = Warsaw, VA) and $2005(\mathrm{Ch}=$ Chocowinity, $\mathrm{NC} ; \mathrm{Fe}=$ Felton, $\mathrm{DE} ; \mathrm{He}=$ Headland, $\mathrm{AL} ; \mathrm{Ki}=$ Kinston, $\mathrm{NC} ; \mathrm{Pa}=$ Painter, VA; Pl = Plains, $\mathrm{GA}$; and $\mathrm{Wa}=$ Warsaw, VA).

Table 1. Origin of wheat powdery mildew isolates recovered in 2003 and 2005 from leaves collected in the field

\begin{tabular}{lcllccc}
\hline Year & State & Location & $\begin{array}{c}\text { Wheat cultivar } \\
\text { or breeding line }\end{array}$ & $\begin{array}{c}\text { No. of plots } \\
\text { sampled }\end{array}$ & $\begin{array}{c}\text { Leaves } \\
\text { sampled }\end{array}$ & $\begin{array}{c}\text { No. of isolates } \\
\text { recovered }\end{array}$ \\
\hline 2003 & NC & Kinston & Coker 9663 & 3 & 12 & 29 \\
2003 & NC & Salisbury & Coker 9663 & 3 & 12 & 30 \\
2003 & GA & Griffin & Coker 9663 & 2 & 3 & 17 \\
2003 & VA & Warsaw & Coker 9663 & 2 & 7 & 20 \\
2003 & KY & Princeton & Jagalene & 1 & 1 & 4 \\
2005 & NC & Kinston & Roane & 3 & 11 & 29 \\
2005 & NC & Chocowinity & Roane & 1 & 3 & 10 \\
2005 & VA & Warsaw & Unknown & 1 & 4 & 9 \\
2005 & VA & Painter & Unknown & 2 & 7 & 19 \\
2005 & DE & Felton & Roane & 1 & 3 & 10 \\
2005 & GA & Plains & P26R61 & 2 & 7 & 20 \\
2005 & AL & Headland & GA951216-2E26 & 2 & 4 & 10 \\
\hline
\end{tabular}

a Each leaf contained numerous cleistothecia. 
were inoculated and, after 8 days, increases were repeated.

Inoculation and rating. Once sufficient conidia were present, each isolate was inoculated onto separate petri plates containing detached leaves of a set of wheat resistance gene differentials, with each differential line bearing a single $P m$ gene, in order to postulate a virulence profile (Table 2). Samples from 2003 were inoculated on 14 differential lines, each containing a different allele. Isolates from 2005 were inoculated on these 14 lines plus 2 more, for a total of 16. Chancellor has no wheat mildew resistance genes (40) and was used in all trials as a susceptible control to detect incomplete inoculation. Experimental units for inoculation were individual petri plates containing all differential lines and susceptible controls. For replication, all differential plates contained two detached leaves from each differential line, and each isolate was inoculated on two plates of the differentials for a total of four leaf segments (two replicates) for each combination of $\mathrm{Pm}$ gene and isolate. Thus, each plate contained 14 differentials for the 2003 isolates and 16 differentials for the 2005 isolates.

Disease severity on each leaf segment was rated 8 and 9 days post inoculation using the following scale: $0=$ no symptoms, 1 = faint chlorosis, $2=$ chlorotic lesion, $3=$ necrotic lesion, $4=$ chlorotic lesion with mycelium, $5=$ one or two pustules with conidia, $6=<20 \%$ coverage with pustules, $7=20$ to $50 \%$ coverage with pustules, $8=>50 \%$ coverage with medium to large pustules, and $9=$ approximately $100 \%$ coverage with large pustules (29). Ratings of 0 to 3 were designated as resistant (R), 4 to 6 as intermediate (I), and 7 to 9 as susceptible (S).

Data analysis. Data were summarized in three categories (resistant, intermediately susceptible, and fully susceptible, or $\mathrm{R}$, I, and S, respectively) in order to char- acterize both the frequencies of virulence at each location and the multilocus virulence phenotype (henceforth virulence phenotype) of each isolate. Intermediately virulent interactions were isolates that grew slowly when inoculated on a particular $P m$ gene but would have been rated $\mathrm{S}$ if allowed to grow several more days. Unless stated otherwise, all analyses were performed with intermediate reactions recoded as susceptible for ease of analysis and continuity with previous virulence studies (34).

Possible associations of alleles at pairs of avirulence loci were investigated by conducting Fisher's exact tests on clonecorrected isolates from both years. Clone correction was performed to prevent biasing the association tests by inadvertent oversampling of particular mildew genotypes. Clone correction was carried out by counting multiple isolates from the same field plot with the same virulence phenotype as a single isolate. Both linkage and independent assortment have been found among avirulence loci in cereal powdery mildews $(3,20)$. Linkage of host resistance loci also could account for associations of avirulence alleles at the corresponding pathogen loci; in this case, a pyramid of defeated resistance genes would rapidly select for multiply virulent pathogen isolates. Assuming an absence of linkage in either host or pathogen, isolates virulent at a given locus should, on average, assort $1: 1$ virulent:avirulent at any other virulence locus. Thus, significant deviations from 1:1 suggest linkage of loci. Fisher's exact tests also were used to determine significant differences in virulence frequencies among geographic locations by comparing the actual and expected frequencies of virulence in tests of all locations together, as well as testing each possible pair of locations.

Virulence phenotypes were analyzed using Map (1) within SNAP workbench ver- sion 1.0 (1,36). Virulence phenotypes were formatted in standard Phylogeny Inference Package (PHYLIP) format (8), and were input into Map to determine frequencies of virulence phenotypes. Isolates that reproducibly generated ambiguous results (both $\mathrm{R}$ and $\mathrm{S}$ on the same differential line) on one or more differential lines were excluded from the analysis. Virulence phenotypes were also evaluated for possible resampling of clones within field plots.

Analysis of geographic differences in virulence frequencies was performed by computing Nei's standard genetic distance $\left(\mathrm{G}_{S T} ; 33\right)$ between sampling locations. This was based on the assumptions that a susceptible differential-isolate interaction indicated a mutation in the avirulence gene corresponding to the respective resistance gene (9) and there were not multiple mutations for virulence to the same allele. To automate this calculation, frequencies of virulence summed over locations were input into GENDIST (8). Rooted trees were inferred from distance matrices using NEIGHBOR with the unweighted pairgroup method with arithmetic mean (UPGMA) and random number seed options from PHYLIP (8). All missing data were excluded from this analysis. It was hypothesized that, as the geographic distance between locations increased, the genetic distance between the corresponding isolate populations would increase. To test whether the data were consistent with an isolation-distance model, $\mathrm{G}_{S T}$ was plotted against geographic distance and a regression analysis was performed.

\section{RESULTS}

In all, 100 isolates from 2003 and 106 isolates from 2005 were recovered from cleistothecial samples (Table 1). Isolates were collected from four states and five locations in 2003 and five states and seven locations in 2005. From samples collected west of the Appalachian Mountains, only

Table 2. Pedigree of powdery mildew $(P m)$ differential wheat lines used in virulence screening of wheat powdery mildew isolates from 2003 and $2005^{\text {a }}$

\begin{tabular}{lll}
\hline Accession number, cultivar name $^{\mathbf{b}}$ & Pm gene & \multicolumn{1}{c}{ Pedigree } \\
\hline CI12333 (Chancellor) & None & Dietz/Carina//Carina/Mediterranean/3/Kanred"S"/Purplestraw \\
CI14114 & $1 a$ & Axminster/8*Chancellor \\
CI14118 & 2 & Ulka/8*Chancellor \\
C114120 & $3 a$ & Asosan/8*Chancellor \\
CI14121 & $3 b$ & Chul/8*Chancellor \\
CI14122 & $3 c$ & Sonora/8*Chancellor \\
CI15888 & $3 f$ & Michigan Amber/8*Chancellor \\
C114123 & $4 a$ & Khapli//*Chancellor \\
NIC (Ronos) & $4 b$ & Graf/Kormoran//Krojuwel \\
CI14125 & $5 a$ & Hope/8*Chancellor \\
NIC & 7 & Transec/8*Chancellor \\
PI361879 (Kavkaz) & 8 & Lutescens 314H147/Bezostaja 1 (=Bezostaja II) (=PI367723) \\
PI520591 (Wembley) & 12 & Hobbit/Sona 227//Sicco \\
NIC Pm16 & 16 & Norman/ T. dicoccoides line \\
PI578213 (Amigo) & 17 & Teewon"S"/6/Gaucho/4/Tascosa/3/Wichita/Teewon/5/2*Teewon \\
CI17452 (TAM-W-104) & 20 & Male sterile Sturdy/PI252003 \\
PI599035 (NC96BGTA5) & 25 & Saluda/PI427662//Saluda/3/Saluda (=NC94-3778) \\
\hline
\end{tabular}

${ }^{\text {a } P m 12}$ and $P m 20$ only used with 2005 isolates.

${ }^{\mathrm{b}}$ Accession numbers from United States Department of Agriculture-Agricultural Research Service Germplasm Resource Information Network. NIC $=$ not in collection. 
four viable isolates could be derived in 2003 (those from Princeton, KY), and none in 2005, despite repeated efforts. Due to the low sample size for Princeton, it is omitted from all analyses.

As few as 1 and as many as 12 leaves produced viable isolates from each location and year. Eight isolates reproducibly provoked inconsistent interactions (virulent and avirulent to the same differential) on one or more differential lines, a phenomenon reported by previous researchers (34). These inconsistent interactions were treated as missing data during frequency analysis of individual virulence loci, and the isolates were omitted from analyses pertaining to virulence phenotypes.

Proportions of isolates virulent to each Pm gene are given in Tables 3 and 4 for the years 2003 and 2005, respectively. In 2003 and 2005 , over $90 \%$ of isolates were virulent to Pm3a, Pm3c, Pm3f, Pm5a, and $P m 7$; virulence to $P m 2$ was present in over
$50 \%$ of isolates; and fewer than $10 \%$ of all isolates were virulent to Pmla, Pml6, $P m 17$, and Pm25. Although it must be kept in mind that sample locations differed between years, mean increases in virulence were observed from 2003 to 2005 as follows: $P m 8$ virulence increased from $7 \%$ of isolates in 2003 to $21 \%$ in 2005; Pm3b virulence from 48 to $66 \%$; and $P m 4 b$ virulence from 42 to $65 \%$. Complete virulence to Pm17 was rare in both 2003 and 2005, with no virulent isolates found in 2003 and only one virulent isolate in 2005 . However, levels of intermediate $\mathrm{Pm} 17$ virulence increased from $9 \%$ in 2003 to $20 \%$ in 2005 .

In total, 27 virulence phenotypes were recovered in 2003 and 42 in 2005; Table 5 indicates all phenotypes comprising greater than $5 \%$ of the population in the 2 years. In 2003, 15 of 27 virulence haplotypes were each found in more than one isolate, with $88 \%$ of sampled isolates possessing shared phenotypes and the remain-

Table 3. Proportion of isolates virulent to wheat powdery mildew $(\mathrm{Pm})$ resistance genes collected from three states in $2003^{\mathrm{a}}$

\begin{tabular}{lccccc}
\hline Genes & $\begin{array}{c}\text { Kinston, NC } \\
(\boldsymbol{n}=\mathbf{2 9})\end{array}$ & $\begin{array}{c}\text { Salisbury, NC } \\
(\boldsymbol{n}=\mathbf{3 0})\end{array}$ & $\begin{array}{c}\text { Griffin, GA } \\
(\boldsymbol{n}=\mathbf{1 7})\end{array}$ & $\begin{array}{c}\text { Warsaw, VA } \\
(\boldsymbol{n}=\mathbf{2 0})\end{array}$ & $\boldsymbol{P}$ value $^{\mathbf{b}}$ \\
\hline Chancellor & 1.00 & 1.00 & 1.00 & 1.00 & $\ldots$ \\
Pm1a & 0.00 & 0.00 & 0.00 & 0.05 & 0.208 \\
Pm2 & 0.45 & 0.80 & 0.47 & 0.50 & 0.000 \\
$P m 3 a$ & 1.00 & 1.00 & 1.00 & 1.00 & $\ldots$ \\
$P m 3 b$ & 0.55 & 0.40 & 0.76 & 0.35 & 0.000 \\
$P m 3 c$ & 1.00 & 1.00 & 1.00 & 1.00 & $\ldots$ \\
$P m 3 f$ & 0.97 & 1.00 & 1.00 & 1.00 & 0.302 \\
$P m 4 a$ & 0.79 & 1.00 & 0.82 & 0.80 & 0.000 \\
$P m 4 b$ & 0.41 & 0.73 & 0.00 & 0.45 & 0.000 \\
$P m 5 a$ & 1.00 & 1.00 & 1.00 & 1.00 & $\ldots$ \\
$P m 7$ & 1.00 & 1.00 & 1.00 & 1.00 & $\ldots$ \\
$P m 8$ & 0.10 & 0.00 & 0.00 & 0.25 & 0.000 \\
$P m 16$ & 0.00 & 0.00 & 0.00 & 0.05 & 0.208 \\
$P m 17$ & 0.14 & 0.10 & 0.00 & 0.00 & 0.008 \\
$P m 25$ & 0.10 & 0.00 & 0.12 & 0.20 & 0.002 \\
\hline
\end{tabular}

${ }^{a} n=$ number of single-ascospore isolates tested from each site.

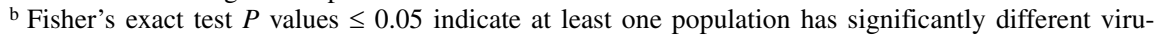
lence frequencies; missing values indicate identical populations where tests could not be performed. ing $12 \%$ having unique phenotypes. In 2005, 14 of 42 virulence haplotypes were each found in more than one isolate (Table 5), with $70 \%$ of isolates possessing shared phenotypes and the remaining $29 \%$ of isolates having unique phenotypes. Combining data from 2003 and 2005 and excluding Pm genes tested only in 2005, $41 \%$ of isolates had one of four virulence phenotypes (Table 5). Of the $14 \mathrm{Pm}$ genes screened in 2003, each mildew isolate was virulent to a minimum of 5 genes and a maximum of 11 (Fig. 2). In 2005, isolates were virulent to a minimum of 7 and a maximum of 13 of the 16 resistance genes screened (Fig. 2).

Possession of the same virulence phenotype, especially among isolates from the same field plot, suggests but does not prove isolate clonality. Within plots, we found varying percentages of virulence phenotype duplicates (Fig. 3). The lowest phenotype diversity was in Felton, with only 4 unique phenotypes among 10 isolates from a single plot in 2005. Diversity in Warsaw, Kinston, and Plains was highest, with over $80 \%$ of sampled isolates having virulence phenotypes unique to their plot. Overall, $67 \%$ of isolates had unique phenotypes in their plots. Virulence phenotypes did not appear to be clustered at any location, except those sampled from Plains, GA in 2005. Due to unusually high levels of virulence to $P m 12$ and complete absence of $P m 4 b$ virulence, all virulence phenotypes in Plains were unique to Plains.

In 2003, there were significant differences among locations in the frequencies of virulence to seven $\mathrm{Pm}$ genes (Table 3). Results of pairwise virulence comparisons of locations in 2003 appear in Table 6. In 2003, isolates from Kinston and Warsaw had the lowest number of significant virulence frequency differences (zero) and isolates from Warsaw and Salisbury had the largest number (five). In 2005, there

Table 4. Proportion of isolates virulent to wheat powdery mildew $(P m)$ resistance genes collected from five states in $2005^{\mathrm{a}}$

\begin{tabular}{|c|c|c|c|c|c|c|c|c|}
\hline Genes & $\begin{array}{c}\text { Kinston, NC } \\
\quad(n=29)\end{array}$ & $\begin{array}{c}\text { Chocowinity, NC } \\
(n=10)\end{array}$ & $\begin{array}{l}\text { Felton, DE } \\
\quad(n=10)\end{array}$ & $\begin{array}{c}\text { Painter, VA } \\
(n=19)\end{array}$ & $\begin{array}{c}\text { Warsaw, VA } \\
\quad(n=9)\end{array}$ & $\begin{array}{l}\text { Plains, GA } \\
\quad(n=19)\end{array}$ & $\begin{array}{l}\text { Headland, AL } \\
\quad(n=10)\end{array}$ & $P$ value $^{b}$ \\
\hline Chancellor & 1.00 & 1.00 & 1.00 & 1.00 & 1.00 & 1.00 & 1.00 & $\ldots$ \\
\hline Pmla & 0.00 & 0.00 & 0.00 & 0.00 & 0.00 & 0.00 & 0.00 & $\ldots$ \\
\hline Pm 2 & 0.55 & 0.60 & 0.50 & 0.74 & 0.56 & 0.63 & 0.30 & 0.000 \\
\hline Pm3a & 1.00 & 1.00 & 1.00 & 1.00 & 1.00 & 1.00 & 1.00 & \\
\hline$P m 3 b$ & 0.62 & 0.30 & 0.70 & 0.89 & 0.78 & 0.42 & 1.00 & 0.000 \\
\hline$P m 3 c$ & 1.00 & 1.00 & 1.00 & 1.00 & 1.00 & 1.00 & 1.00 & $\ldots$ \\
\hline Pm $3 f$ & 1.00 & 1.00 & 1.00 & 1.00 & 1.00 & 1.00 & 1.00 & \\
\hline$P m 4 a$ & 1.00 & 1.00 & 1.00 & 0.89 & 1.00 & 0.53 & 0.50 & 0.000 \\
\hline$P m 4 b$ & 1.00 & 1.00 & 1.00 & 0.84 & 0.33 & 0.00 & 0.00 & 0.000 \\
\hline Pm5a & 1.00 & 1.00 & 1.00 & 1.00 & 1.00 & 1.00 & 1.00 & $\ldots$ \\
\hline $\operatorname{Pm} 7$ & 1.00 & 1.00 & 1.00 & 0.95 & 0.89 & 1.00 & 1.00 & 0.015 \\
\hline Pm8 & 0.10 & 0.20 & 0.00 & 0.05 & 0.22 & 0.89 & 0.00 & 0.000 \\
\hline Pm12 & 0.10 & 0.30 & 0.00 & 0.32 & 0.56 & 1.00 & 0.00 & 0.000 \\
\hline Pm16 & 0.00 & 0.00 & 0.00 & 0.00 & 0.00 & 0.00 & 0.00 & \\
\hline Pm17 & 0.03 & 0.00 & 0.00 & 0.05 & 0.00 & 0.63 & 0.80 & 0.000 \\
\hline Pm20 & 0.66 & 1.00 & 0.90 & 0.84 & 0.56 & 0.95 & 0.70 & 0.000 \\
\hline Pm25 & 0.07 & 0.00 & 0.00 & 0.16 & 0.22 & 0.42 & 0.00 & 0.000 \\
\hline
\end{tabular}

${ }^{\mathrm{a}} n=$ number of single-ascospore isolates tested from each site.

${ }^{\text {b }}$ Fisher's exact test $P$ values $\leq 0.05$ indicate at least one population has significantly different virulence frequencies; missing values indicate identical populations where tests could not be performed. 
were significant differences among locations in the frequencies of virulence to 10 $\mathrm{Pm}$ genes (Table 4). Felton virulence frequencies did not differ significantly from other locations in 2005 (Tables 7 and 8), probably owing to the small Felton sample size. Plains had the largest number of virulence frequency differences (seven each with Kinston and Painter).

Dendrograms for each year based on Nei's genetic distance $\left(\mathrm{G}_{S T}\right)$ matrices for frequencies at each virulence locus appear in Figure 4. These provide a graphical representation of mildew population phenotypic similarities among locations and, as such, reflect the results of the pairwise Fisher's exact tests. Locations with greater similarity of virulence frequencies at all loci are clustered. For the 2 years combined, regression analysis of geographic distance between locations versus genetic distance between locations indicated a significant linear relationship (Fig. $5, R^{2}=$ $0.40, P<0.001$ ), suggesting isolation by distance.

Associations between alleles at pairs of virulence loci were detected by Fisher's exact tests (Table 9). Significant interactions between pairs of loci were categorized as positive or negative associations based on the proportion of the total found in each category. In a positive association, virulence at one locus was associated with virulence at the second locus, or avirulence was associated with avirulence (VV or AA, Table 9). In a negative association, virulence at one locus was associated with avirulence at the other (VA or AV, Table 9). If the sum of $\mathrm{VV}$ and AA was greater than $60 \%$ of the total, the association was positive; if greater than $60 \%$ of the total was $\mathrm{AV}$ and VA, the association was negative. In cases such as $P m 3 b / P m 20$ and Pm8/Pm20, interactions were statistically significant but not clearly negative or positive because both categories were less than $60 \%$ of the total sample size. Positive associations were detected for seven pairs of loci. In the positively associated pairs Pm8/Pm17, Pm8/Pm25, Pm12/Pm17, $P m 12 / P m 25$, and Pm17/Pm25, AA isolates are 50 to $75 \%$ of all isolates. The pairs Pm8/Pm17, Pm8/Pm25, and Pm17/Pm25 have higher proportions of AA and lower proportions of AV or VA isolates than other positively associated pairs.

\section{DISCUSSION}

This is the first survey of eastern U.S. wheat powdery mildew virulence frequencies since Niewoehner and Leath's report (34) on the 1993-94 mildew population.

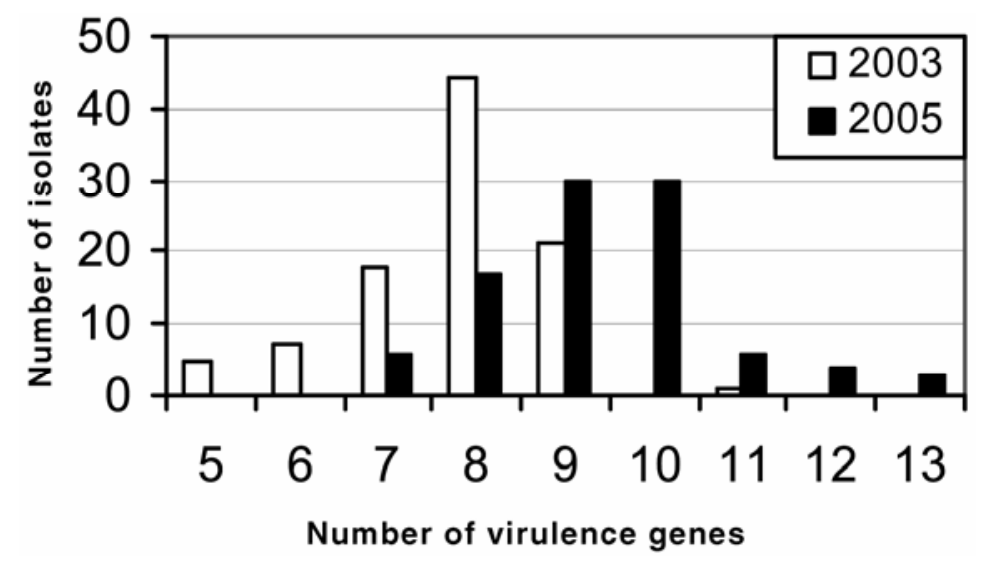

Fig. 2. Complexity (number of virulence genes detected) in wheat powdery mildew isolates sampled in $2003(n=100,14 \mathrm{Pm}$ genes screened) and $2005(n=106,16 \mathrm{Pm}$ genes screened) from 10 locations in the southeastern United States.

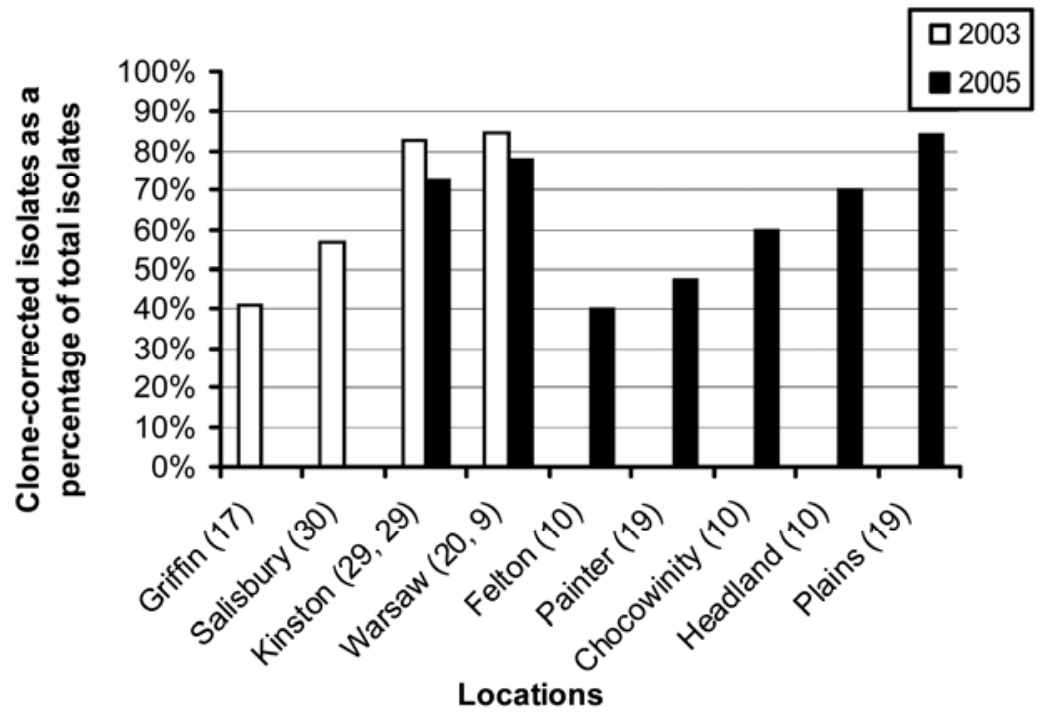

Fig. 3. Clone-corrected isolates as a percentage of total isolates derived from wheat powdery mildew samples from the southeastern United States in 2003 and 2005. Numbers in parentheses after location names are sample sizes in 2003 and 2005, respectively. Clone correction was carried out by counting multilocus virulence phenotypes that occurred more than once in a single field plot as a single isolate.

Table 5. Most frequent virulence phenotypes of wheat powdery mildew isolates collected from four states in 2003 and five states in $2005^{\text {a }}$

\begin{tabular}{|c|c|c|c|c|}
\hline Year & No. of isolates ${ }^{b}$ & $P m$ genes avirulent to & $P m$ genes virulent to ${ }^{c}$ & Frequency $(\%)^{b}$ \\
\hline 2003,2005 & $6(7)$ & $1 \mathrm{a}, 2,3 \mathrm{~b}, 8,(12), 16,17,25$ & $13 \mathrm{a}, 3 \mathrm{c}, 3 \mathrm{f}, 4 \mathrm{a}, 4 \mathrm{~b}, 5 \mathrm{a}, 7,(20)$ & $6.25(7.14)$ \\
\hline 2003,2005 & $5(8)$ & $1 \mathrm{a}, 2,8,(12), 16,17,25$ & $13 \mathrm{a}, 3 \mathrm{~b}, 3 \mathrm{c}, 3 \mathrm{f}, 4 \mathrm{a}, 4 \mathrm{~b}, 5 \mathrm{a}, 7,(20)$ & $5.21(8.16)$ \\
\hline 2003,2005 & $12(7)$ & $1 \mathrm{a}, 3 \mathrm{~b}, 8,(12), 16,17,25$ & $12,3 \mathrm{a}, 3 \mathrm{c}, 3 \mathrm{f}, 4 \mathrm{a}, 4 \mathrm{~b}, 5 \mathrm{a}, 7,(20)$ & $12.5(7.14)$ \\
\hline 2005 & $19^{\mathrm{d}}$ & $1 \mathrm{a}, 8,12,16,17,25$ & $12,3 \mathrm{a}, 3 \mathrm{~b}, 3 \mathrm{c}, 3 \mathrm{f}, 4 \mathrm{a}, 4 \mathrm{~b}, 5 \mathrm{a}, 7,20$ & 19.39 \\
\hline 2003 & 12 & $1 \mathrm{a}, 2,4 \mathrm{~b}, 8,16,17,25$ & $13 \mathrm{a}, 3 \mathrm{~b}, 3 \mathrm{c}, 3 \mathrm{f}, 4 \mathrm{a}, 5 \mathrm{a}, 7$ & 12.50 \\
\hline 2003 & $10^{\mathrm{d}}$ & $1 \mathrm{a}, 8,16,17,25$ & $12,3 \mathrm{a}, 3 \mathrm{~b}, 3 \mathrm{c}, 3 \mathrm{f}, 4 \mathrm{a}, 4 \mathrm{~b}, 5 \mathrm{a}, 7$ & 10.42 \\
\hline 2003 & 9 & $1 \mathrm{a}, 4 \mathrm{~b}, 8,16,17,25$ & $12,3 \mathrm{a}, 3 \mathrm{~b}, 3 \mathrm{c}, 3 \mathrm{f}, 4 \mathrm{a}, 5 \mathrm{a}, 7$ & 9.38 \\
\hline 2003 & 8 & $1 \mathrm{a}, 3 \mathrm{~b}, 4 \mathrm{~b}, 8,16,17,25$ & $12,3 \mathrm{a}, 3 \mathrm{c}, 3 \mathrm{f}, 4 \mathrm{a}, 5 \mathrm{a}, 7$ & 8.33 \\
\hline 2005 & $6^{\mathrm{d}}$ & $1 \mathrm{a}, 8,12,16,17,20,25$ & $12,3 a, 3 b, 3 c, 3 f, 4 a, 4 b, 5 a, 7$ & 6.12 \\
\hline 2003 & 5 & $1 \mathrm{a}, 2,3 \mathrm{~b}, 4 \mathrm{a}, 4 \mathrm{~b}, 8,16,17,25$ & $13 a, 3 c, 3 f, 5 a, 7$ & 5.21 \\
\hline 2005 & 5 & $1 \mathrm{a}, 2,4 \mathrm{~b}, 8,12,16,25$ & $13 a, 3 b, 3 c, 3 f, 4 a, 4 b, 7,17,20$ & 5.10 \\
\hline
\end{tabular}

${ }^{a}$ In all, 27 and 42 virulence phenotypes were detected from 96 samples in 2003 and 98 samples in 2005, respectively. Only those phenotypes comprising $>5 \%$ of the total shown.

b Numbers before parentheses are for 2003 and numbers in parenthesis are for 2005 .

c Genes tested only in 2005 are indicated in parentheses.

d Virulence phenotypes not distinguished from each other by 2003 differentials, but distinguished with the addition of $P m 12$ and $P m 20$ in 2005 . 
Given the potential of this pathogen for rapid adaptation, it was expected that significant changes in some virulence frequencies would be found. Comparison of data on isolates gathered 10 years apart indicates that virulence to some commonly used $P m$ genes increased, while virulence at several alleles remained low or interme- diate. Perhaps the most significant change concerned the high frequency of virulence to $P m 17$ found in the two most southerly sampling locations (discussed below).

Most of the defeated $P m$ genes in our study, such as $P m 2, P m 3 a$, and $P m 5 a$, have been in commercial use for at least 10 years in the United States, and these genes were already ineffective at the time of Niewoehner and Leath's study (34). Virulence to $P m 4 a$, borne by the widely planted cv. Roane (14), increased in North Carolina from intermediate levels in 199394 to high levels in 2003-04 but did not increase in Georgia, where Roane was never widely planted. There were also

Table 6. $P$ values from pairwise location comparisons by Fisher's exact test of virulence frequencies of wheat powdery mildew isolates collected in $2003^{a}$

\begin{tabular}{|c|c|c|c|c|c|c|}
\hline Genes & Kinston/Salisbury & Kinston/Griffin & Kinston/Warsaw & Griffin/Salisbury & Griffin/Warsaw & Salisbury/Warsaw \\
\hline Pmla & & & 0.408 & & 0.541 & 0.400 \\
\hline$P m 2$ & 0.005 & 0.238 & 0.215 & 0.019 & 0.254 & 0.022 \\
\hline Pm $3 a$ & $\ldots$ & & $\ldots$ & $\ldots$ & $\ldots$ & \\
\hline$P m 3 b$ & 0.106 & 0.092 & 0.090 & 0.014 & 0.012 & 0.221 \\
\hline$P m 3 c$ & $\ldots$ & & $\ldots$ & $\ldots$ & $\ldots$ & $\ldots$ \\
\hline$P m 3 f$ & 0.492 & 0.630 & 0.592 & $\ldots$ & $\ldots$ & $\ldots$ \\
\hline $\mathrm{Pm} 4 a$ & 0.011 & 0.293 & 0.280 & 0.042 & 0.320 & 0.021 \\
\hline $\mathrm{Pm} 4 b$ & 0.010 & 0.001 & 0.223 & 0.000 & 0.001 & 0.032 \\
\hline$P m 5 a$ & $\ldots$ & $\ldots$ & $\ldots$ & $\ldots$ & $\ldots$ & $\ldots$ \\
\hline $\mathrm{Pm} 7$ & & & & $\ldots$ & & \\
\hline Pm8 & 0.112 & 0.241 & 0.126 & $\ldots$ & 0.036 & 0.007 \\
\hline Pm16 & $\ldots$ & $\ldots$ & 0.408 & $\ldots$ & 0.541 & 0.400 \\
\hline Pm17 & 0.283 & 0.146 & 0.112 & 0.250 & $\ldots$ & 0.207 \\
\hline Pm 25 & 0.112 & 0.363 & 0.206 & 0.126 & 0.283 & 0.021 \\
\hline
\end{tabular}

${ }^{a} P$ values $\leq 0.05$ indicate significant differences in virulence proportions among or between sites. Missing values indicate populations with identical virulence proportions where no test was possible.

Table 7. $P$ values from pairwise location comparisons by Fisher's exact tests of virulence frequencies of wheat powdery mildew isolates collected in $2005^{a}$

\begin{tabular}{|c|c|c|c|c|c|c|c|c|c|c|}
\hline Genes & $\begin{array}{l}\text { Kinston/ } \\
\text { Felton }\end{array}$ & $\begin{array}{c}\text { Kinston/ } \\
\text { Chocowinity }\end{array}$ & $\begin{array}{l}\text { Kinston/ } \\
\text { Painter }\end{array}$ & $\begin{array}{l}\text { Kinston/ } \\
\text { Warsaw }\end{array}$ & $\begin{array}{l}\text { Chocowin- } \\
\text { ity/Painter }\end{array}$ & $\begin{array}{l}\text { Chocowin- } \\
\text { ity/Warsaw }\end{array}$ & $\begin{array}{l}\text { Chocowin- } \\
\text { ity/Felton }\end{array}$ & $\begin{array}{c}\text { Felton/ } \\
\text { Warsaw }\end{array}$ & $\begin{array}{l}\text { Felton/ } \\
\text { Painter }\end{array}$ & $\begin{array}{l}\text { Painter/ } \\
\text { Warsaw }\end{array}$ \\
\hline \multicolumn{11}{|l|}{ Pmla } \\
\hline Pm2 & 0.274 & 0.279 & 0.108 & 0.297 & 0.244 & 0.350 & 0.315 & 0.344 & 0.146 & 0.212 \\
\hline Pm $3 a$ & & & & & & & & & & \\
\hline$P m 3 b$ & 0.275 & 0.067 & 0.031 & 0.230 & 0.002 & 0.047 & 0.078 & 0.372 & 0.173 & 0.301 \\
\hline$P m 3 c$ & $\ldots$ & $\ldots$ & $\ldots$ & $\ldots$ & $\ldots$ & $\ldots$ & $\ldots$ & $\ldots$ & $\ldots$ & $\ldots$ \\
\hline$P m 3 f$ & $\ldots$ & $\ldots$ & $\ldots$ & $\ldots$ & $\ldots$ & $\ldots$ & $\ldots$ & $\ldots$ & $\ldots$ & \\
\hline $\mathrm{Pm} 4 \mathrm{a}$ & $\ldots$ & $\ldots$ & 0.152 & & 0.421 & & $\ldots$ & & 0.421 & 0.452 \\
\hline $\mathrm{Pm} 4 b$ & $\ldots$ & $\ldots$ & 0.056 & 0.000 & 0.265 & 0.003 & $\ldots$ & 0.003 & 0.265 & 0.008 \\
\hline Pm5a & $\ldots$ & $\ldots$ & $\ldots$ & $\ldots$ & $\ldots$ & $\ldots$ & $\ldots$ & $\ldots$ & $\ldots$ & $\ldots$ \\
\hline $\mathrm{Pm} 7$ & $\ldots$ & $\ldots$ & 0.396 & 0.237 & 0.655 & 0.474 & $\ldots$ & 0.474 & $\ldots$ & 0.226 \\
\hline Pm8 & 0.111 & 0.286 & 0.058 & 0.056 & 0.110 & 0.195 & 0.132 & 0.108 & 0.306 & 0.097 \\
\hline Pm12 & 0.400 & 0.134 & 0.059 & 0.009 & 0.325 & 0.200 & 0.105 & 0.011 & 0.057 & 0.159 \\
\hline Pm16 & & & & & & $\cdots$ & $\cdots$ & $\ldots$ & & \\
\hline Pm17 & 0.744 & 0.744 & 0.191 & 0.763 & 0.421 & & & $\ldots$ & 0.421 & 0.452 \\
\hline Pm20 & 0.120 & 0.032 & 0.101 & 0.261 & 0.265 & 0.033 & 0.500 & 0.108 & 0.408 & 0.103 \\
\hline Pm25 & 0.548 & 0.548 & 0.031 & 0.198 & 0.098 & 0.211 & $\ldots$ & 0.211 & 0.098 & 0.168 \\
\hline
\end{tabular}

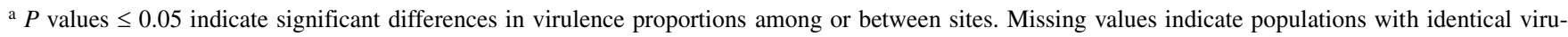
lence proportions where no test was possible.

Table 8. $P$ values from pairwise location comparisons by Fisher's exact tests of virulence frequencies of wheat powdery mildew isolates collected in $2005^{\text {a }}$

\begin{tabular}{lccccccccccc}
\hline Genes & $\begin{array}{c}\text { Kinston/ } \\
\text { Alabama }\end{array}$ & $\begin{array}{c}\text { Chocowin- } \\
\text { ity/Alabama }\end{array}$ & $\begin{array}{c}\text { Felton/ } \\
\text { Alabama }\end{array}$ & $\begin{array}{c}\text { Painter/ } \\
\text { Alabama }\end{array}$ & $\begin{array}{c}\text { Warsaw/ } \\
\text { Alabama }\end{array}$ & $\begin{array}{c}\text { Plains/ } \\
\text { Alabama }\end{array}$ & $\begin{array}{c}\text { Kinston/ } \\
\text { Plains }\end{array}$ & $\begin{array}{c}\text { Chocowin- } \\
\text { ity/Plains }\end{array}$ & $\begin{array}{c}\text { Felton/ } \\
\text { Plains }\end{array}$ & $\begin{array}{c}\text { Painter/ } \\
\text { Plains }\end{array}$ & $\begin{array}{c}\text { Warsaw/ } \\
\text { Plains }\end{array}$ \\
\hline$P m 1 a$ & $\ldots$ & $\ldots$ & $\ldots$ & $\ldots$ & $\ldots$ & $\ldots$ & $\ldots$ & $\ldots$ & $\ldots$ & $\ldots$ & $\ldots$ \\
$P m 2$ & 0.118 & 0.150 & 0.240 & 0.027 & 0.200 & 0.078 & 0.204 & 0.306 & 0.245 & 0.216 & 0.296 \\
$P m 3 a$ & $\ldots$ & $\ldots$ & $\ldots$ & $\ldots$ & $\ldots$ & $\ldots$ & $\ldots$ & $\ldots$ & $\ldots$ & $\ldots$ \\
$P m 3 b$ & 0.021 & 0.002 & 0.105 & 0.421 & 0.211 & 0.002 & 0.096 & 0.262 & 0.117 & 0.002 & 0.073 \\
$P m 3 c$ & $\ldots$ & $\ldots$ & $\ldots$ & $\ldots$ & $\ldots$ & $\ldots$ & $\ldots$ & $\ldots$ & $\ldots$ & $\ldots$ & $\ldots$ \\
$P m 3 f$ & $\ldots$ & $\ldots$ & $\ldots$ & $\ldots$ & $\ldots$ & $\ldots$ & $\ldots$ & $\ldots$ & $\ldots$ & $\ldots$ \\
$P m 4 a$ & 0.000 & 0.016 & 0.016 & 0.028 & 0.022 & 0.300 & 0.000 & 0.009 & 0.009 & 0.013 & 0.013 \\
$P m 4 b$ & 0.000 & 0.000 & 0.000 & 0.000 & 0.033 & 0.655 & 0.000 & 0.000 & 0.000 & 0.000 & 0.010 \\
$P m 5 a$ & $\ldots$ & $\ldots$ & $\ldots$ & $\ldots$ & $\ldots$ & $\ldots$ & $\ldots$ & $\ldots$ & $\ldots$ & $\ldots$ & $\ldots$ \\
$P m 7$ & $\ldots$ & $\ldots$ & $\ldots$ & $\ldots$ & 0.474 & $\ldots$ & $\ldots$ & $\ldots$ & $\ldots$ & $\ldots$ \\
$P m 8$ & 0.400 & 0.238 & 0.500 & 0.265 & 0.087 & 0.000 & 0.000 & 0.000 & 0.000 & 0.000 & 0.001 \\
$P m 12$ & 0.400 & 0.105 & $\ldots$ & 0.057 & 0.011 & 0.000 & 0.000 & 0.000 & 0.000 & 0.000 & 0.006 \\
$P m 16$ & $\ldots$ & $\ldots$ & $\ldots$ & $\ldots$ & $\ldots$ & $\ldots$ & $\ldots$ & $\ldots$ & $\ldots$ & $\ldots$ \\
$P m 17$ & 0.000 & 0.000 & 0.000 & 0.000 & 0.001 & 0.226 & 0.000 & 0.001 & 0.001 & 0.000 & 0.002 \\
$P m 20$ & 0.296 & 0.105 & 0.248 & 0.245 & 0.300 & 0.096 & 0.017 & 0.655 & 0.468 & 0.249 & 0.024 \\
$P m 25$ & 0.548 & $\ldots$ & $\ldots$ & 0.098 & 0.211 & 0.018 & 0.007 & 0.018 & 0.018 & 0.021 & 0.207 \\
\hline
\end{tabular}

${ }^{a} P$ values $\leq 0.05$ indicate significant differences in virulence proportions among or between sites. Missing values indicate populations with identical virulence proportions where no test was possible. 
mixed trends in both time and space with respect to virulence to $P m 4 b$, which is likely present in cultivars planted in the eastern United States. In 1994, Niewoehner and Leath (34) found that $62 \%$ of Georgia isolates and $81 \%$ of North Carolina isolates were virulent to $P m 4 b$ (sample sizes not given). In our survey, $41 \%$ of North Carolina isolates were virulent to $P m 4 b$ in 2003 and $100 \%$ in 2005, whereas no $P m 4 b$-virulent isolates were detected in Georgia either year. Given the infrequent occurrence of large-scale mildew epidemics in Georgia, genetic drift due to a population bottleneck may account for the absence of $P m 4 b$ virulence detected in this survey compared with the high frequency found in the 1994 Georgia sample.
Of the $P m$ genes used in our study, only Pmla, Pm8, Pm12, Pm17, and Pm25 appear to remain effective in the field (authors' personal observations). Virulence data from the present survey were generally consistent with this conclusion but indicated substantially higher levels of virulence in Plains, GA to all these genes except Pmla. Pmla has been available in adapted germplasm in the eastern United States but likely has not been widely deployed until recently; it is currently in commercial use in the North Carolina cv. NC-Neuse (PI633037) (31). By contrast, commercial cultivars with $\operatorname{Pm} 8$ have been in common use for at least 10 years in the eastern United States (34). Pm8 is reported to be defeated in Europe (18) and China (44).

A
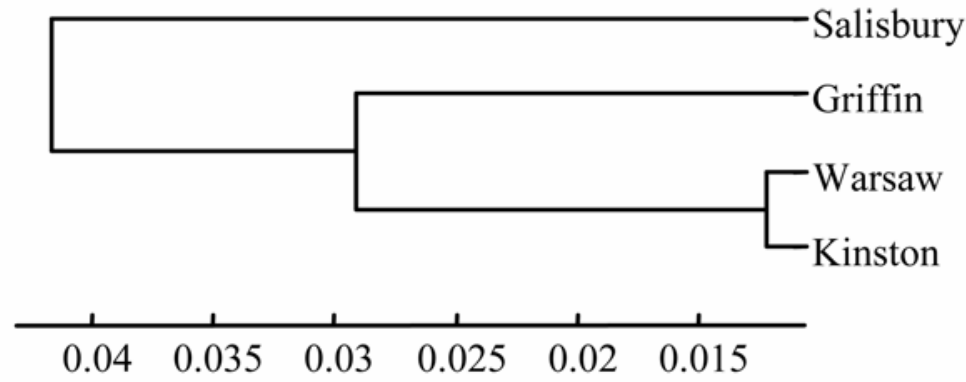

B

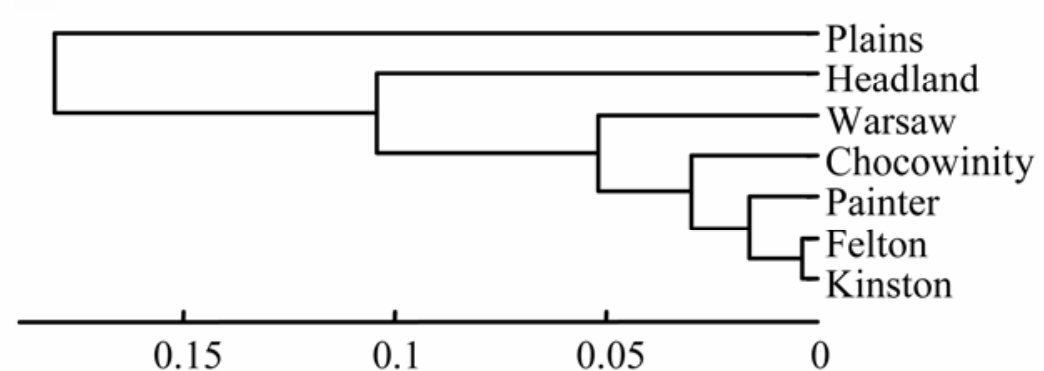

Fig. 4. Nei's standard genetic distance (unitless) among isolates of wheat powdery mildew sampled from A, four locations in 2003 and B, seven locations in 2005, based on frequencies of virulence to $\mathrm{Pm}$ resistance genes. Clustering of locations indicates greater similarity of virulence frequencies among those mildew populations. Scale for branch lengths provided.

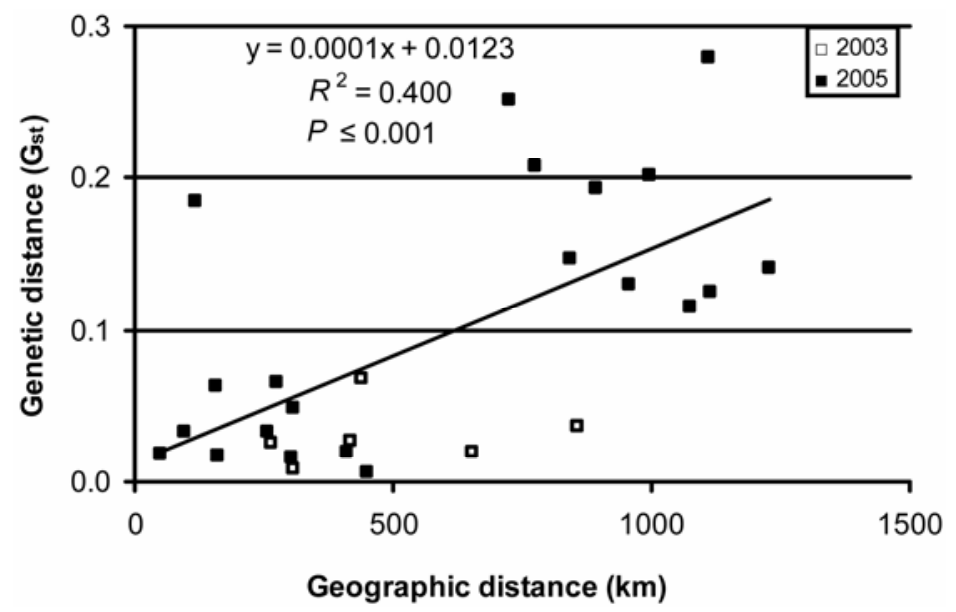

Fig. 5. Pairwise plot of geographic distance versus Nei's genetic distance for 206 wheat powdery mildew isolates sampled from 10 locations in the southeastern United States in 2003 and 2005.

Little or no virulence to Pm12 was detected in North Carolina or Georgia by Niewoehner and Leath (34). Our study found a low level of Pm12 virulence in North Carolina, an intermediate level in Virginia, and a high level in Plains. This gene, derived from Aegilops speltoides (30), has not been widely used in the United States; therefore, it is unclear why virulence should be common in Plains.

Due to the widespread use of cultivars containing Pm17 in North Carolina, Virginia, and Georgia, the high levels of virulence detected in 2005 in the southern part of the region are troubling and could foreshadow a loss in effectiveness of this gene.

Pm25 (37) has not yet been deployed in commercial production; therefore, the mostly low levels of detected virulence to this gene were as expected. However, the intermediate frequency of $P m 25$ virulence found in the Plains, GA samples suggests that this gene might be best deployed farther north in the region.

In the 1993-94 survey, virulence to $\mathrm{Pm} 7$ was at high levels and all but one of the isolates tested in 2003 and 2005 were virulent to $P m 7$. The original source of $P m 7$ was the breeding line 'Transec' (CI14189), a wheat-rye chromosome translocation line that was used in U.S. wheat breeding programs beginning in the late 1960s (6). However, $\operatorname{Pm} 7$ appears to be associated with yield drag (18) and it has not been widely used in U.S. wheat production; therefore, the high frequency of $P m 7$ virulence cannot be explained by host selective pressure. It may be due to hitchhiking selection (4) or the reduced expression that can occur when a resistance gene is transferred from one species to another (18).

The most frequent virulence phenotype comprised $7 \%$ of all survey isolates in 1993-94, with the top four genotypes accounting for $20 \%$ of the total sample (34). In our study, the top four virulence genotypes accounted for $41 \%$ of the sample. If this is a real trend, it could be explained by increasing frequencies of virulence to the most commonly deployed $P m$ genes. However, comparisons between the two studies should be treated with caution due to the differences in sampling methodologies and $P m$ genes employed.

The Fisher's exact tests and Nei's distance analyses reported in Tables 6, 7, and 8 and Figures 4 and 5 address whether differences in virulence among U.S. wheat powdery mildew populations increase with geographic separation. We found an increase in virulence frequency dissimilarity with increasing geographic distance (Fig. 5 ), although the association of genetic and geographic distance was stronger in 2005 than in 2003, likely due to the larger number of sampled locations. There are at least two possible reasons for this association: (i) differences in frequencies of commercially deployed $P m$ genes increase with geographic distance or (ii) mildew popula- 
tions are subdivided geographically, with restricted gene flow among locations. To investigate the second possibility, research is currently underway using markers that are not directly under selective virulence pressure.

Assessments of differences in virulence frequencies between locations obtained by Nei's genetic distance and Fisher's exact tests provided similar but not identical results. For example, for 2003, the dendrogram based on Nei's genetic distance indicated that the Griffin sample was the outgroup (Fig. 4), whereas Fisher's exact analysis identified the Salisbury sample as the most different (Table 6). Fisher's exact test examines each locus independently, whereas Nei's genetic distance accounts for virulence frequencies at all loci in a cumulative, single estimator of distance. As such, Nei's distance is more accurate for presenting overall similarities in virulence among locations as long as the underlying assumptions are correct (constant effective population size, differences between populations arise from drift and mutation, all loci have the same mutation rate; 33 ).

It is puzzling that almost all cleistothecia from west of the Appalachian Mountains failed to mature and release ascospores under controlled conditions conducive to obtaining ascospores from more easterly samples, especially because the 1993-94 study did not have similar difficulties (34). Host maturity and moisture have an important effect on whether cleistothecia become "ripe to spore" $(39,42)$, and our western samples were likely collected from less mature plants than the eastern samples, because collection dates were similar. Also, nutritional deficits during early developmental stages of the "generative" (cleistotheciumforming) mycelia have been reported to prevent cleistothecia from maturing ascospores later (10). In any case, viable conid- ial samples from west of the Appalachians have been obtained and will be included in future population genetic and virulence studies.

Association of alleles at avirulence loci is of interest because it can influence strategies for mildew resistance breeding. Pyramids of currently effective $P m$ genes for which the corresponding avirulence loci are linked (most of the $P m$ gene pairs with the "+" association type in Table 9) should be the most durable because of the low probability of a given isolate assembling virulence mutations at both or all loci, especially if virulence to each pyramided $P m$ gene is at a low level. Even if virulence to particular $P m$ genes is merely low and not absent, it may be useful to deploy such genes in combination, because the probability of the buildup of pathogen isolates with corresponding virulence pyramids is still reduced, especially if the pathogen population can be kept at relatively low levels (5). Across sampled locations, we found the lowest levels of virulence to $P m 8, P m 12, P m 17$, and Pm25. One isolate was fully virulent to all four genes, and seven isolates had full virulence to $P m 8$ and $P m 12$ and intermediate virulence to Pm17 and Pm25 (data not shown). We found low numbers of isolates capable of overcoming all potential two-gene pyramids except those containing Pml6 and Pmla. The relative fitness of these multiply virulent isolates was not tested.

Also interesting are associations, either positive or negative, in which there are high frequencies of virulence to individual $P m$ genes but relatively little virulence at both loci, such as $P m 3 b / P m 8, P m 4 b / P m 8$, and $P m 4 b / P m 12$. In such cases, low proportions of $\mathrm{VV}$ isolates could indicate a fitness cost to combining virulence mutations at the affected loci. Although new resistance genes ideally should be deployed first in pyramids, our results suggest that some pyramids of the studied $\mathrm{Pm}$ genes (such as the pairs with the lowest VV proportions in Table 9) may still be useful in pyramids, given the low levels of existing multiple virulence to them.

Virulences to $P m 8$ and $P m 12$ were positively associated, with about $60 \%$ of isolates avirulent at both loci and about $30 \%$ virulent at both loci (Table 9). Pm12 was introgressed from $A$. speltoides into the U.K. spring wheat cv. Wembley (22). Because this gene is not known to be present in U.S. wheat cultivars, the association of $\mathrm{Pm} 8$ virulence and $\mathrm{Pm} 12$ virulence is not due to the selective effects of a resistance gene pyramid. Rather, it may be the result of pathogen genetic linkage. Positive but weaker associations were observed between virulence to $P m 8$ and $P m 17$, and also $P m 12$ and $P m 25$, suggesting that these loci may be loosely linked in the pathogen. Pm8 and Pm17 are allelic in U.S. wheat cultivars, which possess the T1BL-1RS rye (Secale cereal L.) translocation (17); therefore, the two alleles could be combined only if a plant were heterozygous and the alleles were codominant.

Limited knowledge regarding the identity of $\mathrm{Pm}$ genes present in commercial cultivars and breeding lines, combined with the lack of information on U.S. wheat mildew population structure, constrains interpretation of the virulence frequencies detected. Efforts are underway to postulate powdery mildew resistance genes present in commercial cultivars and breeding lines by molecular marker as well as by challenge with differential mildew isolates. Based on the results from cooperative uniform performance nurseries (unpublished data), we believe that few Pm genes other than those investigated in this study are present in commercial cultivars grown in the eastern United States. This underscores the need to broaden the base of powdery mildew resistance through introgression and deployment of new sources of mildew resistance, including quantitative

Table 9. Linkage between wheat powdery mildew virulence and avirulence loci in clone-corrected sample of 2003 and 2005 isolates from 10 eastern United States locations

\begin{tabular}{|c|c|c|c|c|c|c|c|c|}
\hline \multirow[b]{2}{*}{$P m$ gene pair } & \multicolumn{4}{|c|}{ Pathogen alleles $^{\text {a }}$} & \multirow[b]{2}{*}{ Sum } & \multirow[b]{2}{*}{ VV proportion ${ }^{b}$} & \multirow[b]{2}{*}{ Association type ${ }^{c}$} & \multirow[b]{2}{*}{$P$ value } \\
\hline & $\mathbf{A A}$ & AV & VA & VV & & & & \\
\hline $3 \mathrm{~b} 8$ & 44 & 19 & 62 & 10 & 135 & 0.07 & - & 0.012 \\
\hline $3 \mathrm{~b} 12$ & 14 & 16 & 29 & 11 & 70 & 0.16 & - & 0.018 \\
\hline $3 b 20$ & 4 & 26 & 14 & 26 & 70 & 0.37 & $+1-$ & 0.028 \\
\hline $4 a 4 b$ & 26 & 0 & 42 & 67 & 135 & 0.50 & + & $<0.001$ \\
\hline 4a 12 & 5 & 9 & 38 & 18 & 70 & 0.26 & - & 0.023 \\
\hline $4 \mathrm{~b} 8$ & 47 & 21 & 59 & 8 & 135 & 0.06 & $+/-$ & 0.005 \\
\hline 4b 12 & 8 & 20 & 35 & 7 & 70 & 0.10 & - & $<0.001$ \\
\hline 812 & 42 & 7 & 1 & 20 & 70 & 0.29 & + & $<0.001$ \\
\hline 817 & 95 & 11 & 17 & 12 & 135 & 0.09 & + & $<0.001$ \\
\hline 820 & 16 & 33 & 2 & 19 & 70 & 0.27 & $+1-$ & 0.030 \\
\hline 825 & 96 & 10 & 19 & 10 & 135 & 0.07 & + & 0.002 \\
\hline 1712 & 37 & 16 & 6 & 11 & 70 & 0.16 & + & 0.010 \\
\hline 1725 & 100 & 12 & 15 & 8 & 135 & 0.06 & + & 0.006 \\
\hline 2512 & 42 & 17 & 1 & 10 & 70 & 0.14 & + & $<0.001$ \\
\hline
\end{tabular}

${ }^{a}$ Data are number of isolates virulent (V) or avirulent (A) at respective $P m$ loci (e.g., 44 in the first cell signifies 44 isolates avirulent to $P m 3 b$ and $P m 8$ ).

${ }^{b}$ Proportion of isolates virulent at both avirulence loci.

c Symbols: + indicates significant association is primarily AA or VV and - indicates association is primarily AV or VA.

d Fisher's exact test. 
resistance. The isolates included in this study are also being analyzed with neutral markers to expand our understanding of the evolutionary processes structuring the population. In turn, this should facilitate interpretation of virulence frequencies.

\section{ACKNOWLEDGMENTS}

We thank collaborators who provided mildew samples, including D. Bland, B. Brown, K. Burch, C. Griffey, J. Johnson, B. Mulrooney, and D. Van Sanford; L. Whitcher for her expertise and training; and J. Patton-Özkurt, A. Sutton, and D. Yigit for technical assistance.

\section{LITERATURE CITED}

1. Aylor, D. L., Price, E. W., and Carbone, I. 2006. SNAP: Combine and Map modules for multilocus population genetic analysis. Bioinformatics 22:1399-1401.

2. Brown, J. K. M., and Hovmøller, M. S. 2002. Aerial dispersal of pathogens on the global and continental scales and its impact on plant disease. Science 297:537-541.

3. Brown, J. K. M., and Jessop, A. C. 1995. Genetics of avirulence in Erysiphe graminis $\mathrm{f}$. sp. hordei. Plant Pathol. 44:1039-1049.

4. Brown, J. K. M., and Wolfe, M. S. 1990. Structure and evolution of a population of Erysiphe graminis f. sp. hordei. Plant Pathol. 39:376390.

5. Burdon, J. J. 1993. Genetic variation in pathogen populations and its implications for adaptation to host resistance. Pages 41-56 in: Durability of Disease Resistance. T. Jacobs and J. E. Parlevliet, eds. Kluwer, Dordrecht, The Netherlands.

6. Driscoll, C. J., and Jensen, N. F. 1965. Release of a wheat-rye translocation stock involving leaf rust and powdery mildew resistances. Crop Sci. 5:279-280

7. Felsenstein, F. G., Limpert, E., and Fischbeck, G. 1991. Wheat mildew populations in the FRG and neighboring regions (1986-1988)some aspects of their change. Pages 1-7 in: Integrated Control of Cereal Mildews: Virulence Patterns and Their Change. J. H. Jorgensen, ed. Riso National Laboratory, Roskilde, Denmark.

8. Felsenstein, J. 1989. PHYLIP-Phylogeny Inference Package (version 3.2). Cladistics 5:164-166.

9. Flor, H. H. 1955. Host-parasite interaction in flax-rust-its genetic and other implications. Phytopathology 54:680-685.

10. Götz, M., and Boyle, C. 1998. Haustorial function during development of cleistothecia in Blumeria graminis f. sp. tritici. Plant Dis. 82:507-511.

11. Götz, M., Friedrich, S., and Boyle, C. 1996. Development of cleistothecia and early ascospore release of Erysiphe graminis DC. f. sp. tritici in winter wheat in relation to host age and climatic conditions. Z. Pflanzenkrankh. Pflanzenschutz 103:134-141.

12. Griffey, C. A., Rohrer, W. L., Pridgen, T. H., Brooks, W. S., Chen, J., Wilson, J. A., Nabati, D., Brann, D. E., Rucker, E. G., Behl, H. D., Vaughn, M. E., Sisson, W. L., Randall, T. R., Corbin, R. A., Kenner, J. C., Dunaway, D. W., Pitman, R. M., Bockelman, H. E., Gaines, C., Long, D. L., McVey, D. V., Cambron, S. E., and Whitcher, L. 2005. Registration of 'McCormick' wheat. Crop Sci. 45:416-417.

13. Griffey, C. A., Rohrer, W. L., Pridgen, T. H., Brooks, W. S., Chen, J., Wilson, J. A., Nabati, D., Brann, D. E., Rucker, E. G., Behl, H. D.,
Vaughn, M. E., Sisson, W. L., Randall, T. R., Corbin, R. A., Kenner, J. C., Dunaway, D. W., Pitman, R. M., Bockelman, H. E., Gaines, C., Long, D. L., McVey, D. V., Cambron, S. E., and Whitcher, L. 2005. Registration of 'Tribute' wheat. Crop Sci. 45:419-420.

14. Griffey, C. A., Starling, T. M., Price, A. M., Sisson, W. L., Das, M. K., Pridgen, T. H., Vaughn, M. E., Rohrer, W. L., and Brann, D. E. 2001. Registration of 'Roane' wheat. Crop Sci. 41:1359-1360

15. Hermansen, J. E., Torp, U., and Prahm, L. P. 1978. Studies of transport of live spores of cereal mildew and rust fungi across the North Sea. Grana 17:41-46.

16. Heun, M. 1987. Virulence frequencies influenced by host resistance in the host-pathogen system wheat-powdery mildew. J. Phytopathol. 118:363-366

17. Hsam, S. L. K., and Zeller, F. J. 1997. Evidence of allelism between genes Pm8 and $P m 17$ and chromosomal location of powdery mildew and leaf rust resistance genes in the common wheat cultivar 'Amigo.' Plant Breed. 116:119-122.

18. Hsam, S. L. K., and Zeller, F. J. 2002. Breeding for powdery mildew resistance in common wheat (Triticum aestivum L.). Pages 219-238 in: The Powdery Mildews: A Comprehensive Treatise. R. R. Belanger, W. R. Bushnell, A. J. Dik, and T. L. W. Carver, eds. American Phytopathological Society Press, St. Paul, MN.

19. Hysing, S., Merker, A., Liljeroth, E., Koebner, R. M. D., Zeller, F. J., and Hsam, S. L. K. 2007. Powdery mildew resistance in 155 Nordic bread wheat cultivars and landraces. Hereditas 144:102-119.

20. Jensen, J., Jensen, H. P., and Jorgensen, J. H. 1995. Linkage studies of barley powdery mildew virulence loci. Hereditas 122:197-209.

21. Jevtic, R., Pribakovic, M., Stojanovic, S., and Leath, S. 1991. Screening the virulence of Erysiphe graminis DC. ex Merat f. sp. tritici Em. Marchal in mobile nurseries. Plant Prot. 42:21-31

22. Jia, J., Devos, K. M., Chao, S., Miller, T. E., Reader, S. M., and Gale, M. D. 1996. RFLPbased maps of the homoeologous group-6 chromosomes of wheat and their application in the tagging of $P m 12$, a powdery mildew resistance gene transferred from Aegilops speltoides to wheat. Theor. Appl. Genet. 92:559565.

23. Koltin, Y., and Kenneth, R. 1970. The role of the sexual stage in the over-summering of Erysiphe graminis DC. f. sp. hordei Marchal under semi-arid conditions. Ann. Appl. Biol. 65:263-268.

24. Leath, S. 1991. Wheat powdery mildew in the USA: Status of pathogen virulence and host resistance. Pages 22-32 in: Integrated Control of Cereal Mildews: Virulence Patterns and Their Change. J. H. Jorgensen, ed. Riso National Laboratory, Roskilde, Denmark.

25. Leath, S., and Bowen, K. L. 1989. Effects of powdery mildew, triadimenol seed treatment, and triadimefon foliar sprays on yield of winter wheat in North Carolina. Phytopathology 79:152-155.

26. Leath, S., and Heun, M. 1990. Identification of powdery mildew resistance genes in cultivars of soft red winter wheat. Plant Dis. 74:747752.

27. Leath, S., and Murphy, J. P. 1985. Virulence genes of the wheat powdery mildew fungus, Erysiphe graminis f. sp tritici in North Carolina. Plant Dis. 69:905.
28. Limpert, E., Felsenstein, F. G., and Andrivon, D. 1987. Analysis of virulence in population of wheat powdery mildew in Europe. J. Phytopathol. 120:1-8

29. Lipps, P. E., and Madden, L. V. 1989. Assessment of methods of determining powdery mildew severity in relation to grain yield of winter wheat cultivars in Ohio. Phytopathology 79:462-470.

30. Miller, T. E., Reader, S. M., and Ainsworth, G. C. 1988. The introduction of a major gene for resistance to powdery mildew of wheat, Erysiphe graminis f. sp. tritici, from Aegilops speltoides into wheat, Triticum aestivum. In: Proceedings of EUCARPIA. Pudoc, Wageningen, The Netherlands.

31. Murphy, J. P., Navarro, R. A., Leath, S., Bowman, D. T., Weisz, P. R., Ambrose, L. G. Pate, M. H., and Fountain, M. O. 2004. Registration of 'NC-Neuse' wheat. Crop Sci. 44:1479-1480.

32. Namuco, L. O., Coffman, W. R., Bergstrom, G C., and Sorrells, M. E. 1987. Virulence spectrum of the Erysiphe graminis f. sp. tritic population in New York. Plant Dis. 71:539 541.

33. Nei, M. 1972. Genetic distance between populations. Am. Nat. 106:283-292.

34. Niewoehner, A. S., and Leath, S. 1998. Virulence of Blumeria graminis f. sp. tritici on winter wheat in the eastern United States. Plant Dis. 82:64-68

35. Persaud, R. R., and Lipps, P. E. 1995. Virulence genes and virulence gene frequencies of Blumeria graminis f. sp. tritici in Ohio. Plant Dis. 79:494-499.

36. Price, E. W., and Carbone, I. 2004. SNAP: workbench management tool for evolutionary population genetic analysis. Bioinformatics 21:402-404.

37. Shi, A. N., Leath, S., and Murphy, J. P. 1998. A major gene for powdery mildew resistance transferred to common wheat from wild einkorn wheat. Phytopathology 88:144-147.

38. Slovakova, T., Svec, M., and Miklovicova, M. 2004. Do geographical barriers play any role in isolation of powdery mildew populations? Biologia (Bratislava) 1:121-126.

39. Smedegard-Petersen, V. 1967. Studies on Erysiphe graminis DC. with a special view to the importance of the perithecia for attacks on barley and wheat in Denmark. K. Vet. Landbohoejsk. Arsskr. 77:1-28.

40. Srni, G., Murphy, J. P., Lyerly, J. H., Leath, S., and Marshall, D. S. 2005. Inheritance and chromosomal assignment of powdery mildew resistance genes in two winter wheat germplasm lines. Crop Sci. 45:1578-1586.

41. Svec, M., and Miklovicova, M. 1998. Structure of populations of wheat powdery mildew (Ery siphe graminis DC. f. sp. tritici Marchal) in Central Europe in 1993-1996: I. Dynamics of virulence. Eur. J. Plant. Pathol. 104:537-544.

42. Turner, D. M. 1956. Studies on cereal mildew in Britain. Trans. Br. Mycol. Soc. 39:495-506.

43. Tursumbaev, A. 1974. Some biological characteristics of the causal agent of wheat powdery mildew. Vestn. Skh. Nauki. Kaz. 17:29-33.

44. Wang, Z. L., Li, L. H., He, Z. H., Duan, X. Y., Zhou, Y. L., Chen, X. M., Lillemo, M., Singh, R. P., Wang, H., and Xia, X. C. 2005. Seedling and adult plant resistance to powdery mildew in Chinese bread wheat cultivars and lines. Plant Dis. 89:457-463.

45. Wolfe, M. S., and Schwarzbach, E. 1978 Patterns of race changes in powdery mildews. Annu. Rev. Phytopathol. 16:159-80. 